\title{
EVALUATION OF GAS EXCHANGES IN DIFFERENT Prunus SPP. ROOTSTOCKS UNDER DROUGHT AND FLOODING STRESS ${ }^{1}$
}

\author{
ELSA KUHN KLUMB², LETICIA NEUTZLING RICKES ${ }^{3}$, \\ EUGENIA JACIRA BOLACEL BRAGA ${ }^{4}$, VALMOR JOÃO BIANCHI ${ }^{5}$
}

\begin{abstract}
The state of Rio Grande do Sul is the largest peach productor in Brazil; however, it still possesses poor yield values when compared with other states. One of the problems associated with this is the occurrence of soils with drainage problems, mainly in Pelotas region, which depending on the year period, may undergo water deficit or flooding situations in the great majority of the years, which harm the crop development and yield. Among the harmful effects caused by these stresses stand out, the decrease in the net assimilation rate, closure of stomata, reduction of the cell activities, production of reactive oxygen species, membrane and protein destabilization. Thus, the aim of this study was to investigate in what magnitude of the gaseous exchange parameters of Prunus spp. rootstocks are influenced under drought and flood stress. In the experiment, gas exchange parameters net photosynthetic rate $(A)$ stomata conductance $(g s)$, intercellular carbon $(C i)$ and transpiration $(E)]$ were evaluated in three Prunus spp. rootstocks (peach tree 'Capdeboscq' and plum trees 'Julior' and 'Marianna 2624') under three water conditions (control, water deficit and soil flooding) for seven days. The three rootstocks proved more susceptible to flooding than to water deficit, only varying in response time, which is intrinsic to each genotype, and that there is a genetic variability for the tolerance to the studied stresses. The variation on physiological response to the water deficit stress was later in both evaluated genotypes. However, in general, 'Julior' presented greater tolerance to both stresses when compared to the other rootstocks evaluated. Such information is useful to help in the choice of rootstocks for plant production, in the orchard management and for plant breeding programs, aiming at the selection of new genotypes with increased tolerance to these water stresses.
\end{abstract}

Index terms: water stress, photosynthesis, peach tree, plum tree.

\section{PARÂMETROS DE TROCAS GASOSAS EM DIFERENTES PORTA ENXERTOS DE Prunus SPP. SUBMETIDOS AO ESTRESSE POR SECA E ALAGAMENTO}

RESUMO- O Estado do Rio Grande do Sul é o detentor da maior produção de pêssegos do Brasil; entretanto, ainda possui valores baixos de produtividade, quando comparado com outros estados. Um dos problemas associados a isto é a ocorrência de solos com problemas de drenagem, principalmente na região de Pelotas que, dependendo do período do ano, podem sofrer situações de déficit hídrico ou de alagamento, na grande maioria dos anos, que prejudicam o desenvolvimento e a produtividade da cultura. Dentre os efeitos prejudiciais causados por estes estresses, destacam-se a diminuição na taxa assimilatória líquida, fechamento de estômatos, a redução das atividades celulares, a produção de espécies reativas de oxigênio e a desestabilização de membranas e de proteínas. Desta forma, o objetivo deste trabalho foi investigar em que magnitude os parâmetros de trocas gasosas de porta-enxertos de Prunus spp. são influenciados sob estresse por seca e alagamento. No experimento, foram avaliados parâmetros de trocas gasosas [taxa fotossintética líquida $(A)$ condutância estomática $(g s)$, carbono intercelular $(C i)$ e transpiração $(E)$ ], em três porta-enxertos de Prunus spp. (pessegueiro 'Capdeboscq' e ameixeiras 'Julior' e 'Marianna 2624'), em três condições hídricas (controle, déficit hídrico e alagamento do solo), durante sete dias. Os três porta enxertos demonstraram ser mais suscetíveis ao alagamento do que ao déficit hídrico, apenas variando no tempo de resposta, que é intrínseco a cada genótipo, evidenciando existir variabilidade genética para a tolerância aos estresses estudados. A resposta ao estresse por déficit hídrico foi mais tardia em ambos os genótipos avaliados. Entretanto, no geral 'Julior' apresentou maior tolerância a ambos os estresses em relação aos outros portaenxertos avaliados. Tais informações são úteis para auxiliar na escolha de porta-enxertos para a produção de mudas, no manejo de pomares, e para programas de melhoramento de plantas, visando à seleção de novos genótipos com maior tolerância a esses estresses abióticos.

Termos para indexação: estresse hídrico, fotossíntese, pessegueiro, ameixeira.

'(Paper 025-16). Received January 28, 2016. Accepted July 05, 2016.

2Doctoral student in Plant Physiology, Biology Institute, Botany Department, UFPel, Pelotas-RS, Brasil. E-mail: elsakk91@yahoo.com.br ${ }^{3}$ Doctor in Plant Physiology, Biology Institute, Botany Department, UFPel. E-mail: leticiarickes@hotmail.com

${ }^{4}$ Associate Professor of the Biology Institute, Botany Department, UFPel. E-mail: jacirabraga@hotmail.com

${ }^{5}$ Associate Professor of the Biology Institute, Botany Department, UFPel. E-mail: valmorjb@yahoo.com.br 


\section{INTRODUCTION}

In Brazil, the main species of stone fruit cultivated is the peach tree [Prunus persica (L.) Batsch], belonging to the family Rosaceae and Prunus genus, reaching the $14^{\text {th }}$ position in the ranking of world peach production (FAOSTAT, 2015), where the Southern states stand out for presenting climatologic conditions which support its commercial exploration (EMBRAPA, 2005) and the state of Rio Grande do Sul is the largest national producer (IBGE, 2015).

Although holders of the greatest national production of peaches, the Rio Grande do Sul orchards possess indices of average yield considered low $\left(\approx 10 \mathrm{t} \mathrm{ha}^{-1}\right)$ when compared with other States such as São Paulo and Minas Gerais which had an average yield of above $20 \mathrm{tha}^{-1}$ (SOUZA et al., 2013) and among the factors associated with that lies the shortage of studies about the responses of rootstocks to biotic and abiotic stresses. Such rootstocks can be coming from both peach cultivars and from other species of the genus Prunus, as of plum trees, since grafting compatibility takes places. According to Pimentel et al. (2014) species of Prunus are considered sensitive to hypoxia, although, there is variability for the tolerance among different cultivars. Fachinello and Bianchi (2005) related that other fact associated with the poor yield is the model of peach rootstock production which occurs in most cases through the use of stones obtained in agroindustry canned peaches. That sort of material possesses no control of genetic and sanitary quality, influencing negatively on the plant growth, production and yield of stone fruits.

Water stress is recurring environmental factors in Rio Grande do Sul since the southern zone of this state is characterized for presenting extensive areas of hydromorphic soils, poorly permeable and with drainage problems (CUNHA and SILVEIRA, 1996). Added to that, in the great majority of the years, annual average rainfall is considered high $(\approx 1,500 \mathrm{~mm})$, but, not always is well distributed along the year, which can cause flooding due to excess of raining in certain periods (MARTINAZZO et al., 2013).

Although, plants need free access to water for nutrient absorption, excess water around roots can be harmful or even lethal, since it reduces drastically the transfer of free oxygen between the soil solution and the atmosphere (PISTELLI et al., 2012). This condition, decreasing the oxygen levels in the environment around the roots, inducing root asphyxia and greatly damaging critical periods of the crop, as it is the case of the blossoming period and beginning of sprouting (MARTINAZZO et al., 2013). On the other hand, almost every year, some region of the earth is affected by water deficit, damaging crops and harming or even interrupting agricultural production (NAKASHIMA et al., 2014). Such situation can be find in the state of Rio Grande do Sul in the months comprehended among November and January, where the rainfall deficit periods are recurrent, and being able to take the plant to undergo a drought stress in the period which precedes fruit ripening, affecting in a crucial manner their quality and the orchard yield (MARTINAZZO et al., 2013).

Water stress, both by drought and for flooding, affect the wood plants' metabolism, since gene expression, and the production and consumption of energy until plant growth and development (PIMENTEL et al., 2014). A series of studies has reported that the photosynthetic process is progressively reduced in plants submitted to water stress conditions, at first as a protective effect as well as in consequence of the stomata closure, decrease of the leaf area and decrease of the chlorophyll content in the leaf (MARTINAZZO et al., 2013, PIMENTEL et al., 2014), resulting into significant physiological restraints which can cause severe falls in plant yield (NAKASHIMA et al., 2014).

This study aimed to evaluate the effect of flooding and water deficit on the photosynthetic activity in three different Prunus spp. rootstock.

\section{MATERIAL AND METHODS}

Plants of peach tree cultivar 'Capdeboscq' (Prunus persica), considered susceptible to soil flooding; plum tree cultivar 'Julior' (P. insititia L. $x$ P. domestica L.), which presents tolerance to relatively long periods of hypoxia; and cultivar Marianna 2624 (P. cerasifera Ehrh. $x$ P. munsoniana Wight \& Hedr.), which presents good adaptability to heavy and wet soils, were propagated by cutting, cultivated in 5-liter pots, containing orchard soil, classified as typical dystrophic red-yellow argisol (SCHMITZ et al., 2014), and maintained in greenhouse with controlled temperature $\left( \pm 30^{\circ} \mathrm{C}\right)$, with high temperatures ranging $42-43^{\circ} \mathrm{C}$ (daytime) and minimum temperatures between $18-21^{\circ} \mathrm{C}$ (night-time) and humidity of about 
$80 \pm 5 \%$. When the plants were 10 months old, the experiment started, which consisted in the induction of water stress, with the complete suspension of watering (water deficit stress), maintenance of water height of about $3 \mathrm{~cm}$ above soil level (flooding stress) and a group of control plants, which were kept at field capacity. The gas exchange parameters were evaluated daily for a seven-day period for both stresses (water deficit and flooding).

The measurements of the gas exchanges conducted between 9 a.m. and 11a.m. were carried out on the same leaves and on two leaves per plant, these being ripe, completely expanded and situated at the medium third of each branch, using a portable infrared $\mathrm{CO}_{2}$ analyzer (model LI-6400XT, LI-COR, Inc., Lincoln, NE, USA). The $\mathrm{CO}_{2}$ concentrations in the chamber were adjusted to $380 \mathrm{~mol} \mathrm{~mol}^{-1}$, photon flux density of $1,200 \mu \mathrm{mol} \mathrm{m} \mathrm{m}^{-2} \mathrm{~s}^{-1}$ and the temperature inside the chamber was always kept around $28^{\circ} \mathrm{C} \pm 2^{\circ} \mathrm{C}$. The experimental design was completely randomized for each cultivar independently in factorial scheme $3 \times 7$, being three water conditions (control, water deficit and flooding) and seven days evaluation. Each treatment consisted of three replicates, each represented by one plant and two readings per plant, totalizing six determinations per treatment and cultivar.

The results obtained were evaluated by means of the statistical program WinStat (version 1.0), where analysis of variance was conducted and the means compared within each day of the experiment and each cultivar through the Tukey test $(p<0.05)$.

\section{RESULTS AND DISCUSSION}

The net photosynthetic rate $(A)$ of the plants of the peach tree cv. Capdeboscq presented significant reduction of the values from 48 hours (two days) of stress for the water deficit and flooding conditions in relation to the control plants, behavior that followed until the last evaluation day (fourth day for flooding and seventh day for water deficit) (figure 1A). The stomatal conductance ( $g s)$ demonstrated significant difference for the flooding stress from the 24 hours (one day), where gradual drop of the means till the fourth day of experiment was obtained (figure 1B). However, on the fourth day of stress, the plants presented reduction of around $50 \%$ in the values of $g s$ when compared with the control and for the following days, the values did not reach one third of the value recorded in the control plants, reaching on the last day with a value of $g s \quad 80 \%$ lower compared to the control.

For the intercellular carbon $(C i)$, it was found that the control plants kept quite stable throughout the period of the experiment, but the plants exposed to flooding, showed a significant decrease on the second day of the experiment, followed by a significant increase of the means for this variable on the third and fourth days. On the other hand, under water deficit the plants presented a more marked fall only on the fourth day of stress, afterwards, returning to values between 300.7 and $318.7 \mu \mathrm{mol} \mathrm{CO}_{2} \mathrm{~mol}^{-1}$ by the end of the evaluation period (figure $1 \mathrm{C}$ ). The transpiration rate $(E)$ of the plants under water deficit stress had a significant drop in relation to the control plants from the fourth day of stress and, afterwards, their values were always kept smaller in relation to the control until the end of the experiment. The flooded plants had presented lower values for this parameter since the first days of stress, reaching values close to zero, at third $\left(0.82 \mathrm{mmol} \mathrm{H}_{2} \mathrm{O} \mathrm{m}^{-2} \mathrm{~s}^{-1}\right)$ and fourth day $(0.34$ mmol $\mathrm{H}_{2} \mathrm{O} \mathrm{m}^{-2} \mathrm{~s}^{-1}$ ) of stress (figure 1D).

The plum tree rootstocks of cultivar 'Julior' presented similar behavior for net photosynthesis rate $(A)$ (figure $2 \mathrm{~A}$ ) and transpiration rate $(E)$ (figure 2D). For these variables, by the sixth day of evaluation in both stress conditions (water deficit and flooding), when evaluated within each day and compared to the control no significant differences were recorded, standing out on the seventh day, more drastic reduction in the values for the flooding stress as compared to those of water deficit. For the variable stomatal conductance ( $g s$ ) (figure 2B), similar behavior occurred with that observed in the other variables investigated on 'Julior', with the exception of the third day of stress, where the control differed significantly from the plants submitted to stress. But the variable $C i$ did not follow the same tendency as compared to the others evaluated on 'Julior', their values obtained an increase and presented greater when compared with the control (figure 2C).

'Marianna 2624', another cultivar of plum tree evaluated in this study, obtained different results from those found in 'Julior during the experiment. For the parameters of net photosynthetic rate $(A)$ and stomatal conductance $(g s)$, although the plants of 'Marianna 2624' presented higher values of $A$ (10-13 $\left.\mu \mathrm{mol} \mathrm{CO} \mathrm{CO}^{-2} \mathrm{~s}^{-1}\right)$ and $g s\left(0.6-0.9 \mu \mathrm{mol} \mathrm{H}_{2} \mathrm{O}\right.$ $\left.\mathrm{m}^{-2} \mathrm{~s}^{-1}\right)$ in control plants as compared with cultivar Julior $\left[A\left(4-8 \mu \mathrm{mol} \mathrm{CO} \mathrm{CO}^{-2} \mathrm{~s}^{-1}\right)\right.$ and $g s(0.3-0.5$ $\left.\mu \mathrm{mol} \mathrm{H}_{2} \mathrm{O} \mathrm{m}^{-2} \mathrm{~s}^{-1}\right)$ ], this behavior did not remain 
stable over the days in stressed plants, as noted in 'Julior'. The plants of 'Marianna 2624' submitted to flooding presented significant differences compared to the control or water deficit, since the first day of the experiment for $A$ and from the second day for gs. Plants subjected to water stress obtained more reduced $g s$ values relative to the control since the first day, but significant statistical difference was only observed from the fourth day of the experiment (figures 3A and 3B). For the other two gas exchange parameters in 'Marianna 2624' plants, it is found that the intercellular carbon $(\mathrm{Ci})$ presented significant difference in the values only on the fourth and sixth day of the experiment as compared to the control, for the water deficit treatment and at 24 and 48 hours for flooding (figure $3 \mathrm{C}$ ). For transpiration rate $(E)$, the flooded plants obtained values significantly lower than the control since the first day of submission to stress. In the plants under water stress, only from the fourth day their values began to decrease significantly compared to the control and remained so until the last day of evaluation (figure 3D).

Based on the results obtained, it was possible to find that the responses of the rootstocks of Prunus spp. towards effects of water stress depend on several factors, such as imposed types of stress (drought or flooding), their time of duration and especially on the level of tolerance of the genotype, which was notably discrepant, especially when comparing different species (peach tree and plum tree). It is known and reported by several authors in the literature, that water stress provides strong impacts to plants' metabolism, the reduction in photosynthetic capacity and stomatal conductance being considered limiting and triggering several other harmful processes (FERNER et al., 2012; PIMENTEL et al., 2014; KREUZWIESER and RENNENBERG, 2014). According to Kreuzwieser and Rennerberg (2014) there are strong indications that limitations on both stomatal and non-stomatal are involved in the progressive reduction of photosynthetic capacity in plants subjected to environmental stresses.

The stomatal closure process occurs in response to the stress due to turgor decline in the leaf, chemical signals generated in the roots or by the vapor pressure deficit (FLEXAS et al., 2007; CHAVES et al., 2009). This response is initially considered plant protecting, since it prevents the excess water loss, helping the plant to utilize water in more efficient manner (CHAVES et al., 2009).
However, if stress becomes more lasting and severe, the reduction in stomatal conductance ends on progressively harming the photosynthesis process, since the furnishing of $\mathrm{CO}_{2}$ to Rubisco (ribulose-1,5-bisphosphate carboxylase/oxygenase) becomes difficult, making the use of all light energy for the production of ATP and $\mathrm{NADPH}_{2}$ impossible, which predisposes to increased energy dissipation by the photosynthesis apparatus and the negative regulation of photosynthesis, increasing thus the susceptibility to photo inhibition (CHAVES et al., 2009; NAKASHIMA et al., 2014).

Both decreases in the values of $A$ and $g s$ events were observed in the experiment conducted and in the three genotypes evaluated, but for the cultivar 'Julior' this occurred only on the last stress day, where it obtained significant reduction in the values of $A$ and $g s$ both for the flooding and water stress treatment. The flooding treatment demonstrated to be more aggravating to the plants of all the genotypes evaluated as compared with water deficit for all the variables $A$ and $g s$, and for the cultivar 'Capdeboscq' (Prunus persica) a determinant factor to the development of the study, for on the fourth day the plants had already lost all their leaves, preventing their continuity and demonstrating thus to be highly sensitive to flooding stress. Messchmidt et al. (2015) observed similar response to the cultivar Capdeboscq in relation to flooding susceptibility, but their plants survived until the eighth day of stress. That difference is explained, likely, due to the high temperatures added to the flooding faced by the plants in the period of the present experiment, which provided an abrupt fall in three out of the four gas exchange parameters evaluated by the fourth day, where the plants underwent serious leaf abscission, preventing the experiment continuity.

The stomatal closure and reduction in post-water stress net photosynthesis have been reported in Prunus (MARTINAZZO et al., 2011; MARTINAZZO et al., 2013; PIMENTEL et al., 2014). In trials where rootstocks of ' $G X N-9$ ' hybrid (Prunus dulcis Mill. Prunus persica L. $\times$ Bastsch) were utilized, Martinazzo et al. (2011) also observed greater severity imposed by the flooding stress than by water deficit, but the 'GXN-9' plants began to show significant fall in the values of $A$ and $g s$ only on the seventh and eighth day of the experiment. Martinazzo et al. (2013) studying the plum tree cv. America (Prunus salicina) found fall in the photosynthetic 
parameters evaluated from the fourth and fifth day of stress, however, on the contrary of the observed in this study with cultivar 'Julior', the plum tree 'America' demonstrated more serious consequences for the water deficit treatment as compared with flooding. In a similar experiment, Pimentel et al. (2014) submitted 'Marianna 2624' plants to flooding and, in surveying both $A$ and $g s$, decreased in the parameters only on the $14^{\text {th }}$ day of stress and the plants' survival rate were of $100 \%$. However, they recorded maximum temperatures ranging between 25 and $30^{\circ} \mathrm{C}$, values well below those occurred in the period of the present study, which peaks were around $42^{\circ} \mathrm{C}$. Warm days and with intense solar radiation significantly increase the amount of water transpired by leaves and under stress, the amount of water absorbed by roots and transported through the xylem is little or null (depending on the intensity of stress), hampering thereby further the $\mathrm{CO}_{2}$ entry into the leaf and consequently, photosynthesis (CHAVES et al., 2009).

The decrease of the stomatal conductance values also has direct influence on other parameters such as intercellular carbon $(\mathrm{C} i)$ and transpiration rate (E). The analysis of $C i$ describes the carbon dioxide availability for the photosynthetic process (DUCAT and SILVER, 2012), and the reduction of $C i$ may be related to the occurrence of stomatal limitations (CHAVES et al., 2009), since stomatal and mesophyll resistance reduce the $\mathrm{CO}_{2}$ concentration, which may reach other structures such as the chloroplast (MARTINAZZO et al., 2013). Therefore, under stress conditions, $C i$ tends to a decrease in its values, having in mind that the stomatal conductance is reduced, thus limiting the entry of $\mathrm{CO}_{2}$ through the stomata. Such behavior has been observed in other studies conducted in Prunus by Martinazzo et al. (2011, 2013), Rouhi et al. (2007) and Pimentel et al. (2014); and this study was discretely checked in plum trees cultivar 'Marianna 2624', on the first and second day of stress for the flooded plants and on the fourth and sixth days for water deficit treatment, where their obtained values differed in relation to the control plants. Different behavior was observed in plants of the rootstock 'Capdeboscq' submitted to flooding, where on the last day of evaluation (third and fourth) reached a significant increase in the values of $C i$. The same occurred in 'Julior' on the same days but for the water deficit treatment. According to Chaves et al. (2009), an increase of $C i$ can be attributed to a heterogeneous stomatal closure and/or interference of the cuticular conductance; however, Rouhi et al. (2007) attribute this fact to non-stomatal limitations. Rouhi et al. (2007) also observed high leaf abscission in genotypes of Prunus compared to water deficit and also to which occurred in this study, the $C i$ values obtained significant increase under this condition. Aschan and Pfanz (2003) explain that non-stomatal limitations are observed under conditions of severe stress and high leaf abscission and depend directly on the degree of tolerance of the studied genotype.

Due to the cuticle being almost waterimpermeable, most of the leaf transpiration rate $(E)$ results from the diffusion of water vapor through the stomata and values of $E$ depend upon two main factors: i) difference of water vapor concentration between the intercellular spaces of leaves and external atmospheric mass; and ii) diffusion resistance to this pathway (TAIZ and ZEIGER, 2013). However, as previously discussed, under stress conditions, the stomatal openings remain small or closed, limiting the entry of $\mathrm{CO}_{2}$ as well as water loss. This effect was observed in all cultivars evaluated in this experiment, differing only in the response time against the stress, having in mind the different level of tolerance that each genotype presents. 
(A) *
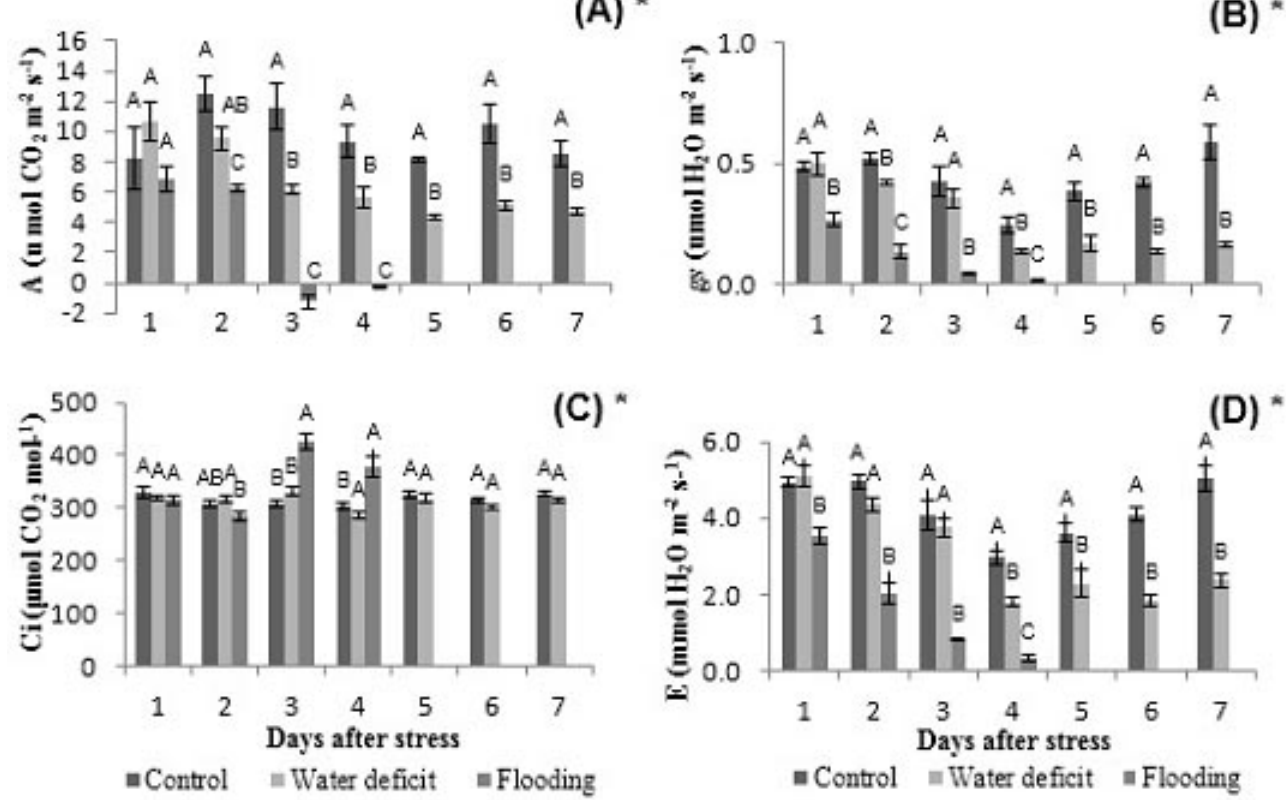

FIGURE 1- Net photosynthetic rate $(A)$, stomatal conductance $(g s)$, intercellular carbon $(C i)$ and transpiration rate $(E)$ of peach tree rootstocks cv. Capdeboscq submitted to water stress (water stress and flooding) for seven days. The bars indicate the standard error of the mean of three replications. Means compared within each day for a given cultivar and followed by the same letter do not differ from one another by the Tukey test at $5 \%$ of probability $(n=3)$. *Evaluations of the plants submitted to flooding ceased after the fourth day of stress due to excess leaf abscission as they presented during the stress period.
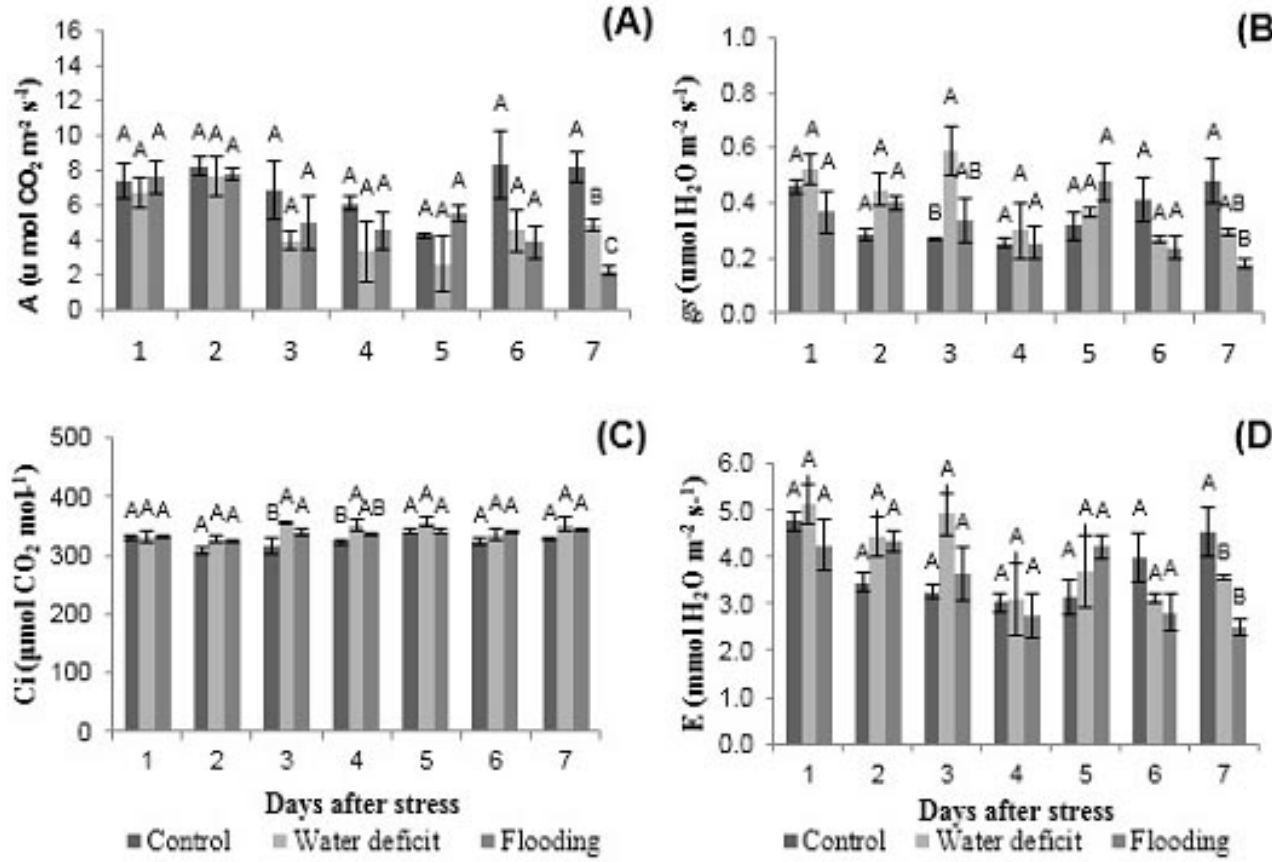

(C)

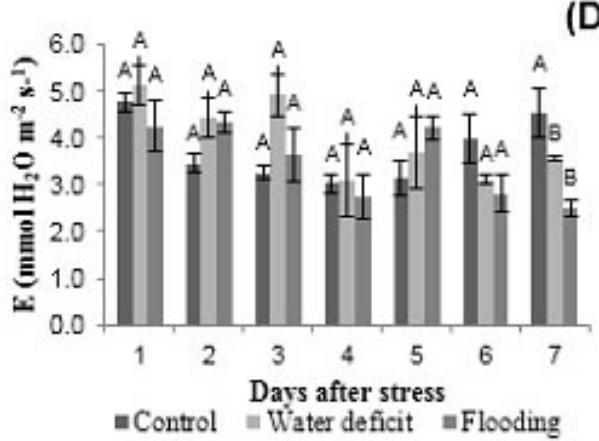

(D)

FIGURE 2-Net photosynthetic rate $(A)$, stomatal conductance $(g s)$, intercellular carbon $(C i)$ and transpiration rate $(E)$ of plum tree rootstocks cv. 'Julior' submitted to water stress (water stress and flooding) for seven days. The bars indicate the standard error of the mean of three replications. Means compared within each day for a given cultivar and followed by the same letter do not differ from one another by the Tukey test at $5 \%$ of probability $(n=3)$. 

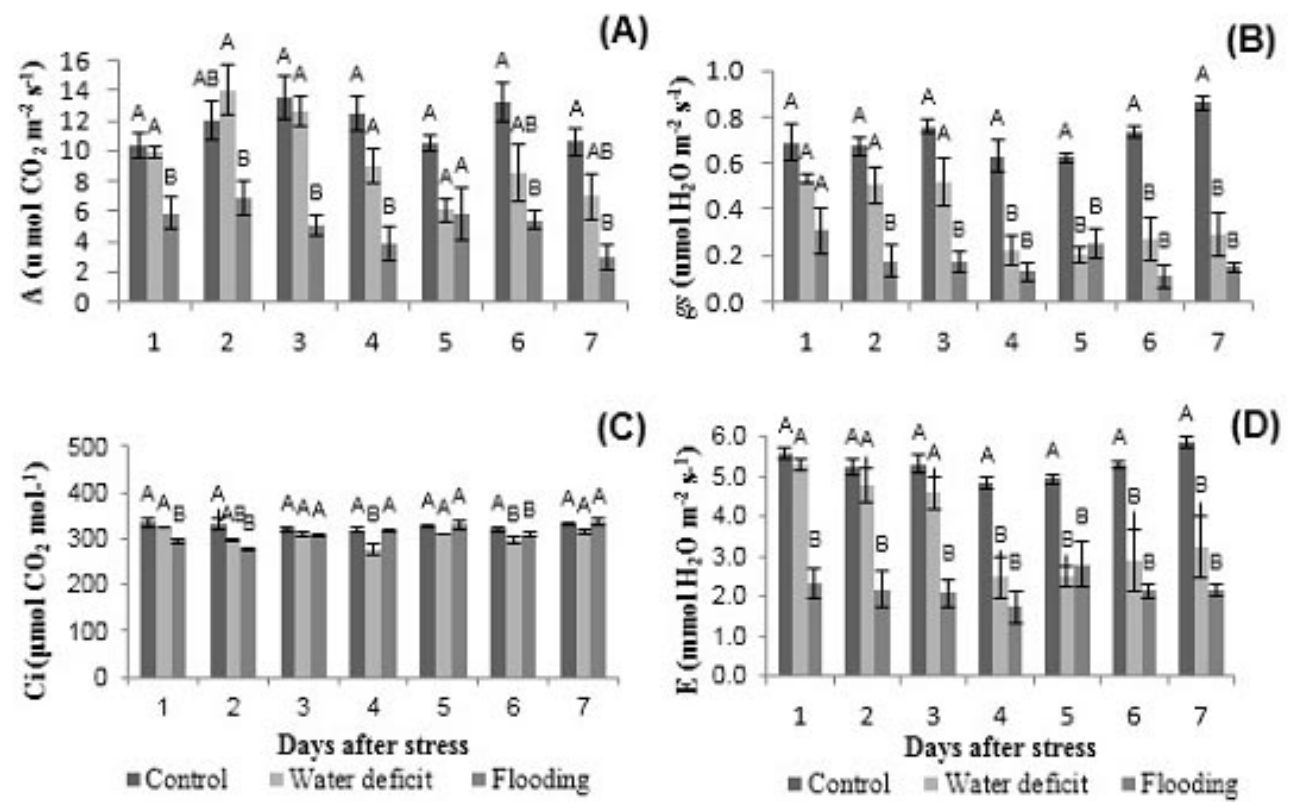

(C)

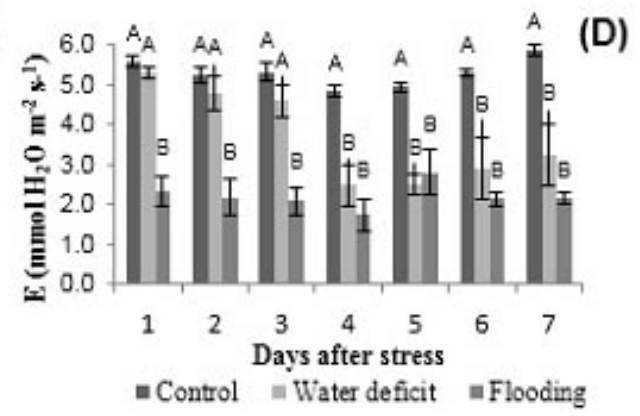

FIGURE 3- Net photosynthetic rate $(A)$, stomatal conductance $(g s)$, intercellular carbon $(C i)$ and transpiration rate $(E)$ of plum tree rootstocks cv. 'Marianna 2624' submitted to water stress (water stress and flooding) for seven days. The bars indicate the standard error of the mean of three replications. Means compared within each day for a given cultivar and followed by the same letter do not differ from one another by the Tukey test at $5 \%$ of probability $(n=3)$.

\section{CONCLUSIONS}

It was possible to find that the cultivars of plum trees studied in the present experiment showed greater flooding stress tolerance when compared with the peach tree cultivar Capdeboscq. It was also possible to infer that the response to water deficit stress was later, which means that such plants present greater tolerance to such stress as compared to soil flooding. Such results indicate the existence of variability among genotypes of Prunus spp. to water deficit and flooding conditions and such information can be used to help in the management of orchards and breeding of rootstocks.

\section{ACKNOWLEDGEMENTS}

The authors are thankful to the Brazilian Research Council (CNPq), Coordination of Support to Superior Education (CAPES) and Rio Grande do Sul State Agency for Support to Research (FAPERGS) for grants and fellowships.

\section{REFERENCES}

ASCHAN, G.; PFANZ, H. Non-foliar photosynthesis-a strategy of additional carbon acquisition. Flora, Munich, v.198, n.2, p.81-97, 2003.

CHAVES, M. M. Photosynthesis under drought and salt stress: regulation mechanisms from whole plant to cell. Annals of Botany, Oxford, v.103, p.551-560, 2009.

CUNHA, N.G.; SILVEIRA, R.J.C. Estudo dos solos do município de Pelotas. Pelotas: EMBRAPA/ CPACT; UFPel, 1996. 50p.

DUCAT, D. C.; SILVER, P. Improving carbon fixation pathways. Current Opinion in Chemical Biology, London, v.16, n.1, p.1-8, 2012.

EMBRAPA. O Cultivo do pêssego. Pelotas: Embrapa Clima Temperado, 2005. (Sistemas de Produção, 4) 
FACHINELLO, J.C.; BIANCHI, V.J. Porta-enxertos para frutas de caroço: banco ativo de germoplasma (BAG) e atividades de pesquisa na UFPel. In: SIMPÓSIO BRASILEIRO DE RECURSOS GENÉTICOS, 2005, Pelotas. Resumos e Palestras... Pelotas: Embrapa Clima Temperado, 2005. v.1, p.103-107.

FERNER, E.; RENNENBERG, H.; KREUZWIESER, J. Effect of flooding on C metabolism of floodtolerant (Quercus robur) and non-tolerant (Fagus sylvatica) tree species. Tree Physiology, Oxford, v.32, n.1, p.135-145, 2012.

FLEXAS, J.; DIAZ-ESPEJO, A.; GALME'S, J.; KALDENHOFF, R.; MEDRANO, H.; RIBASCARBO, M. Rapid variations of mesophyll conductance in response to changes in $\mathrm{CO}_{2}$ concentration around leaves. Plant, Cell $\&$ Environment, Oxford, v.30, n.1, p.1284-1298, 2007.

FOOD AND AGRICULTURE ORGANIZATION OF THE UNITED NATIONS. FAOSTAT. Available in: $<$ http://www.fao.org/faostat/en/\#data/QC $>$. Access in: 09 dez. 2015.

IBGE. Database. 2015. Available in: $<$ http:// www.sidra.ibge.gov.br/bda/agric/default. asp? $\mathrm{z}=\mathrm{t} \& \mathrm{o}=11 \& \mathrm{i}=\mathrm{P}>$. Access in: 09 dez. 2015.

KREUZWIESER, J.; RENNENBERG, H. Molecular and physiological responses of trees to waterlogging stress. Plant, Cell and Environment, Oxford, v.10, n.1, p.2245-2259, 2014.

MARTINAZZO, E.G., PERBONI, A.T., FARIAS, M.E., BIANCHI, V.J.; BACARIN, M.A. Photosynthetic activity in the rootstock of hybrid peach trees submitted to water restriction and flooding. Brazilian Journal Plant Physiology, Viçosa, v.23, n.3, p.231-236, 2011.

MARTINAZZO, E.G.; PERBONI, A.T.; OLIVEIRA, P.V.; BIANCHI, V.J.; BACARIN, M.A. Atividade fotossintética em plantas de ameixeira submetidas ao déficit hídrico e ao alagamento. Ciência Rural, Santa Maria, v.43, n.1, p.35-41, 2013.
MESSCHMIDT, A.A.; BIANCHI，V.J.; ZANANDREA, I.; MARTINAZZO, E.G.; BACARIN, M.A. Trocas gasosas e atividade antioxidante de portaenxertos de Prunus spp. submetidos ao estresse seca e alagamento. Revista de la Facultad de Agronomía, La Plata, v.114, n.1, p.71-81, 2015.

NAKASHIMA, K.; YAMAGUCHI-SHINOZAKI, K.; SHINOZAKI, K. The transcriptional regulatory network in the drought response and its crosstalk in abiotic stress responses including drought, cold, and heat. Frontiers in Plant Science, Switzerland, v.5, n.170, p.1-7, 2014.

PIMENTEL, P.; ALAMADA, R.D.; SALVATIERRA, A.; TORO, G.;ARISMENDI, M.J.; PINTO, M.T.; SAGREDO, B.; PINTO, M. Physiological and morphological responses of Prunus species with different degree of tolerance to long-term root hypoxia. Scientia Horticulturae, Amsterdan, v.180, n.1, p.14-23, 2014.

PISTELLI, L.; LACONA, C.; MIANO, D.; CIRLLI, M.; COLAO, M.C.; MENSUALI-SODI,A.; MULEO, R. Novel Prunus rootstock somaclonal variants with divergent ability to tolerate waterlogging. Tree Physiology, Oxford, v.32, n.1, p.355-368, 2012.

ROUHI, V.; SAMSON, R.; LEMEUR, R.; DAMME, P.V. Photosynthetic gas exchange characteristics in three different almond species during drought stress and subsequent recovery. Environmental and Experimental Botany, Oxford, v.59, n.1, p.117129, 2007.

SCHMITZ, J.D.; PASA, M.S.; FISCHER, D.L.O.; FACHINELLO, J.C.; BIANCHI, V.J. Desempenho de porta-enxertos em diferentes sistemas de cultivo na produção de mudas do pessegueiro 'Chimarrita'. Revista Ceres, Viçosa, MG, v.61, n.2, p.1-7, 2014.

SOUZA, F.B.T.; ALVARENGA, A.A.; PIO, R.; GONÇALVES, E.D.; PATTO, L.S. Produção e qualidade dos frutos de cultivares e seleções de pessegueiro na Serra da Mantiqueira. Bragantia, Campinas, v.72, n.2, p.133-139, 2013.

TAIZ, L.; ZEIGER, E. Fisiologia vegetal. 5.ed. Porto Alegre: Artmed, 2009. 918p. 